GRASAS Y ACEITES 72 (4)

October-December 2021, e430

ISSN-L: 0017-3495

https://doi.org/10.3989/gya.0890201

\title{
Fatty acid composition, phytochemicals and antioxidant potential of Capparis spinosa seeds
}

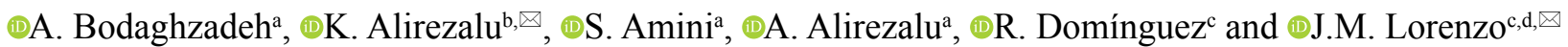 \\ ${ }^{a}$ Department of Horticultural Sciences, Faculty of Agriculture, Urmia University, Urmia, Iran. \\ ${ }^{b}$ Department of Food Science and Technology, Ahar Faculty of Agriculture and Natural Resources, University of Tabriz, Tabriz, Iran. \\ ${ }^{\circ}$ Centro Tecnológico de la Carne de Galicia, Parque Tecnológico de Galicia, rúa Galicia n 4, San Cibrao das Viñas, Ourense 32900, Spain \\ ¿Área de Tecnología de los Alimentos, Facultad de Ciencias de Ourense, Universidad de Vigo, 32004 Ourense, Spain \\ ${ }^{\circledR}$ Corresponding authors: jmlorenzo@ceteca.net; kazem.alirezalu@tabrizu.ac.ir
}

Submitted: 17 August 2020; Accepted: 12 October 2020; Published online: 13 January 2022

SUMMARY: The present study evaluates the contents in bioactive compounds, antioxidant activity, oil content and fatty acid composition of Capparis spinosa seeds. Samples were collected from 5 different habitats (AH: Ahar; KU: Kurdistan; U1, U2 and U3: Urmia) in Iran. The oil content in the seeds ranged from 16 to $27 \%$. The predominant fatty acid was linoleic acid (45-50\%) followed by oleic acid (30-39\%), palmitic acid (2-8\%) and stearic acid (2-3\%). Total phenolic content (TPC) varied from 16.3 to $24.2 \mathrm{mg}$ GAE/ g DW; total flavonoid content (TFC) ranged from 1.48 to $3.05 \mathrm{mg} \mathrm{QE} / \mathrm{g}$ DW; and the antioxidant activity (DPPH assay) of the seeds was between 35 and $63 \%$. The compounds obtained from different genotypes of $C$. spinosa seeds had different compositions, great antioxidant capacity and unsaturated fatty acids, and therefore could be a prospective source of natural bioactive molecules for the food and health industry.

KEYWORDS: Antioxidant activity; Bioactive compounds; Fatty acids; Flavonoids; Phenolic compounds

RESUMEN: Composición de ácidos grasos, fitoquímicos y potencial antioxidante de las semillas de Capparis spinosa. El presente estudio evaluó el contenido de compuestos bioactivos, actividad antioxidante, contenido de aceite y composición de ácidos grasos de las semillas de C. spinosa. Se recolectaron muestras de cinco hábitats diferentes (AH: Ahar; KU: Kurdistán; U1, U2 y U3: Urmia) en Irán. El contenido de aceite de las semillas osciló entre el 15,66 y el 27,50\%. El ácido graso predominante fue el ácido linoleico (45-50\%) seguido por el oleico (30-39\%), el palmítico (2-8\%) y el esteárico (2-3\%). El contenido fenólico total varió de 16,3 a 24,2 mg GAE/g DW; el contenido total de flavonoides entre 1,48 y $3,05 \mathrm{mg} \mathrm{QE} / \mathrm{g} \mathrm{DW}$; la actividad antioxidante de las semillas estuvo entre 34,68 y $62,74 \%$. Los compuestos obtenidos de semillas de C. spinosa tienen gran capacidad antioxidante y ácidos grasos insaturados, por lo que podrían ser una fuente de moléculas bioactivas naturales en la industria alimentaria y de la salud.

PALABRAS CLAVE: Ácidos grasos; Actividad antioxidante; Compuestos bioactivos; Compuestos fenólicos; Flavonoides

Citation/Cómo citar este artículo: Bodaghzadeh A, Alirezalu K, Amini S, Alirezalu A, Domínguez R, Lorenzo JM. 2021. Fatty acid composition, phytochemicals and antioxidant potential of Capparis spinosa seeds. Grasas Aceites 72 (4), e430. https://doi.org/10.3989/ gya.0890201

Copyright: (C2021 CSIC. This is an open-access article distributed under the terms of the Creative Commons Attribution 4.0 International (CC BY 4.0) License. 


\section{INTRODUCTION}

The caper is a perennial shrub plant and is the common name of the genus Capparis, in the family Capparidaceae. It is distributed in the subtropical and tropical regions with 250 species (Wojdyło et al., 2019). The taxonomy of the genus in Iran has been the subject of much debate. Boissier (1867), combined Capparis parviflora and Capparis mucronifolia species in the Capparis spinosa as varieties. However, Zohary (1960) introduced five species with several varieties in Iran. Capparis spinosa, with three varieties, var. spinosa, var. parviflora and var. Mucronifolia, has been cited in In Flora Iranica (Hedge and Lamond, 1970). Capparis species are mostly distributed in the south of Iran, however, Capparis spinosa is widely distributed in all regions of Iran.

Different organs of caper-like fruits and flower buds are commonly used by the local population for their anti-inflammatory, antidiabetic, antihyperlipidemic, antihypertensive, antihepatotoxic and anticarcinogenic activities since the caper and its derivatives, such as pickled caper buds are rich in vitamins, essential minerals, fatty acids and proteins (Özcan et al., 2004; Arslan and Özcan, 2007; Özcan, 2008; Bakr and El Bishbishy, 2016). C. spinosa seeds are rich in lipids, containing unsaturated fatty acids (Oleic acid, vaccenic acid, linoleic acid), bioactive (phenolic compounds) and nutraceutical (flavonoids and sterols) compounds (Matthäus and Özcan, 2005). However, Duman and Özcan (2014) reported that capers had high levels of $\mathrm{Ca}, \mathrm{K}, \mathrm{Mg}, \mathrm{Na}$, and $\mathrm{S}$ minerals but caper seeds involved more mineral matter than oils. During the last decade, several natural compounds such as synthetic additive replacers (Domínguez et al., 2020; Lorenzo et al., 2018) have been investigated in the food industry. C. spinosa is a possible source of these compounds. C. spinosa seeds contain a relatively high amount of oil (23-33\%) (El-Waseif and Badr, 2018), rich in phospholipids (phosphatidylinositol), with a high content in tocopherols ( $\gamma$-tocopherols and $\delta$-tocopherols), sterols (sitosterol, campesterol and stigmasterol), carotenoids ( $\alpha$-tocopherol) and glucosinolates (Glucocapperin) (Matthäus and Özcan, 2005; Tlili et al., 2009; Zhang and Ma, 2018).

It is well known that the genotype and region could exert a great impact on the oil composition and functional and nutritional properties (Alirezalu et al., 2016). However, there are limited data relating to the effects of genotype and location on C. spinosa oil composition. In addition to environmental conditions that have considerable effects on the biosynthesis of secondary metabolites, genetic factors can also contribute to the biosynthesis and accumulation of these compounds. The interaction of environmental factors and the genetic background of plants play a substantial role in the accumulation of metabolites (Alirezalu et al., 2018; Shaghaghi et al., 2019; Alirezalu et al., 2020). Some genes contribute to the biosynthesis of fatty acids and phenolics in medicinal plants. The expression of these genes varies in various species. Moreover, cytochromes-P450 isoforms contribute to the phenylpropanoid metabolism and by effecting several reactions, they regulate phenolic synthesis (Ayabe and Akashi, 2006).

The purpose of the present study was to determine, for the first time, oil content, fatty acid composition, phytochemicals and antioxidant activity of the oil from caper seeds collected from 5 different regions.

\section{MATERIALS AND METHODS}

\subsection{Sample preparation}

The ripe fruits of $C$. spinosa genotypes (accession) from 5 region of West Iran were collected from 27 June until 10 July 2016 (Table 1). Details of collection sites are presented in Table 1. The seeds were obtained from ripened fruit (5 plants from every region). The freezedried fruits were squashed in a mortar and sifted using a 60-mesh screen to separate the seeds from the pulp. After air-drying at $30^{\circ} \mathrm{C}$ for $72 \mathrm{~h}$, seeds were removed, mixed and used for additional analysis (Fazio et al., 2013).

\subsection{Oil extraction}

For this study, $5 \mathrm{~g}$ of a powdered sample from each plant seed were extracted by hexane solvent $(300 \mathrm{~mL})$ using a Soxhlet extractor for $5 \mathrm{~h}$ at $80^{\circ} \mathrm{C}$ in order to prevent damage to minor compounds. The extract was filtered through filter papers containing sodium sulphate and vacuum evaporated (around $150 \mathrm{mbar}$ ) in a rotary evaporator until the $\mathrm{n}$-Hexane portions were removed at $40{ }^{\circ} \mathrm{C}$ and then stored $-20^{\circ} \mathrm{C}$ for further analysis. The oil content in the seeds was expressed on a percent basis, based on whole samples. Oil content was then measured using Equation 1.

(\%) Oil content $=\left(\mathrm{W}_{1}-\mathrm{W}_{2}\right) / \mathrm{W}_{3} \times 100$ Eq. 1 $\mathrm{W}_{1}=$ Weight of dried sample befor extraction + filter bag $\mathrm{W}_{2}=$ Weight of dried sample after extraction + filter bag $\mathrm{W}_{3}=$ Original weight of simple

\subsection{Fatty acid analysis}

Fatty acid methyl esters (FAMEs) were prepared from the oil samples according to the method described by Savage et al. (1997). FAME) and were derived from the esterification of $20 \mathrm{mg}$ extracted oil with $2 \mathrm{~mL} 0.01 \mathrm{M}$ $\mathrm{NaOH}$ in dry methanol at $60^{\circ} \mathrm{C}$ for 30 min under continuous shaking and transesterification of glycerolipids with boron trichloride/methanol. The FAMEs were determined by GC (Agilent technologies, $6890 \mathrm{~N}$, USA) according to the method reported by Azadmard-Damirchi and Dutta 
TABLE 1. Sampling locations of the different caper genotypes.

\begin{tabular}{|c|c|c|c|c|c|}
\hline \multirow{2}{*}{ Code } & \multirow{2}{*}{ Species } & \multirow{2}{*}{ Collection sites } & \multicolumn{3}{|c|}{ Geographical location } \\
\hline & & & Longitude (N) & Latitude (E) & Altitude (m) \\
\hline $\mathrm{AH}$ & C. spinosa & East Azerbaijan /Ahar (Qareh daq) & $38^{\circ} 47^{\prime} 32.72^{\prime \prime}$ & $47^{\circ} 11^{\prime} 54.84$ “ & 2172 \\
\hline KU & C. spinosa & Kurdistan / Kurdistan & $34^{\circ} 16^{\prime} 58.41^{\prime \prime}$ & $47^{\circ} 01^{\prime} 07.86^{\prime \prime}$ & 1553 \\
\hline U1 & C. spinosa & West Azerbaijan/Urmia(1) & $37^{\circ} 45^{\prime} 17.82^{\prime}$ & $44^{\circ} 42^{\prime} 31.68^{\prime \prime}$ & 1735 \\
\hline $\mathrm{U} 2$ & C. spinosa & West Azerbaijan/Urmia(2) & $37^{\circ} 20^{\prime} 31.37^{\prime \prime}$ & $45^{\circ} 08^{\prime} 57.87^{\prime}$ & 1350 \\
\hline U3 & C. spinosa & West Azerbaijan/Urmia(3) & $37^{\circ} 27^{\prime} 39.13^{\prime \prime}$ & $44^{\circ} 57^{\prime} 05.86^{\prime \prime}$ & 1624 \\
\hline
\end{tabular}

(2006). The GC instrument was equipped with a capillary injection valve and DB-Wax capillary column (30 $\mathrm{m} \mathrm{x}$ $0.25 \mathrm{~mm}$ i.d and $0.25 \mu \mathrm{m}$ of thickness), which was treated with polyethylene glycol and a flame ionization detector (FID). The FAMEs were analyzed by comparison of their retention times with standard FAMEs and the peak areas are reported as a percentage of the total fatty acids.

\subsection{Preparation of seed extract}

One $\mathrm{g}$ of caper seed was powdered by liquid nitrogen and extracted with $20 \mathrm{~mL}$ of $80 \%$ methanol, then mixed gradually for $1 \mathrm{~h}$ using a magnetic stirrer. The extract was filtered using filter paper (Whatman No.1). The resulting extract was kept at $-70{ }^{\circ} \mathrm{C}$ for corresponding analysis.

\subsection{Total phenolic content (TPC)}

The TPC in the seed extracts was determined by Folin-Ciocalteau method Singleton et al. (1999) with some modification. Briefly, $100 \mu \mathrm{L}$ of methanolic extracts were shaken for $1 \mathrm{~min}$ with $1 \mathrm{~mL}$ of diluited (1:10) Folin-Ciocalteu reagent and held at $25^{\circ} \mathrm{C}$ for $5 \mathrm{~min}$. Then $800 \mu \mathrm{L}$ of sodium carbonate $(10 \%)$ were added and the final volume was made up to $5.0 \mathrm{~mL}$ with distilled water. After that, the mixture was left at room temperature for $2 \mathrm{~h}$. Finally, the absorbance at $760 \mathrm{~nm}$ was measured by a spectrophotometer (UNICO, China). Gallic acid was expressed as a standard solution and TPC was used as mg GAE/g DW.

\subsection{Total flavonoid content (TFC)}

The TFC was measured by an adapted colorimetric method using aluminium chloride $\left(\mathrm{AlCl}_{3}\right)$ (Ordoñez et al., 2006). Briefly, $400 \mu \mathrm{L}$ of seed extract were added to 0.3 $\mathrm{mL}$ distilled water followed by $0.03 \mathrm{~mL} \mathrm{NaNO}_{2}(5 \%)$. The mixture was held for $5 \mathrm{~min}$ at $25^{\circ} \mathrm{C}$, and then $0.03 \mathrm{~mL}$ of $\mathrm{AlCl}_{3}(10 \%)$ were added. After $5 \mathrm{~min}$, the mixture was treated with $0.2 \mathrm{~mL}$ of $1 \mathrm{mM} \mathrm{NaOH}$. Finally, the reaction was diluted to $100 \mathrm{~mL}$ with distilled water. The absorbance versus prepared blank was measured at $420 \mathrm{~nm}$. TFC was reported as mg of quercetin equivalents per $\mathrm{g}$ of sample dry weight (mg of QE/g DW).

\subsection{Antioxidant activity}

To measure the antioxidant activity by the DPPH (2, 2'-diphenyl-1-picrylhydrazyl) free radical scavenging method, $500 \mu \mathrm{L}$ of methanolic extracts were mixed with 1 $\mathrm{mL}$ of the DPPH solution. The mixture was held in the dark at $20{ }^{\circ} \mathrm{C}$ for $30 \mathrm{~min}$. Absorbance was determined at 517 $\mathrm{nm}$ using UV-Vis spectrophotometer (UNICO, China). The percentage of inhibition (I\%) of free radical DPPH was calculated using the formula: RSA\% $=[($ Ablank - Asample $) /$ Ablank] × 100 (Nakajima et al., 2004).

\subsection{Statistical analysis}

All of the analyses ( 5 regions $\times 5$ sampling point $\times 3$ experiments) were carried out in a completely randomized design. SAS 9.1.3 software package (SAS Institute, US) was used for statistical analysis of the data. Normal distribution and variance homogeneity had been previously tested (Shapiro-Wilk). The data were submitted to oneway analysis of variance (ANOVA). The different parameters studied in the present research were included in the model as dependent variables, while genotype was included as a fixed effect. Duncan's test was carried out when the ANOVA was significant $(P<0.05)$, in order to determine differences between means. The principal component analysis (PCA) and hierarchical cluster analysis (HCA) based on Ward's method and correlation analysis based on Pearson's method were performed among the variables (fatty acid composition) by MINITAB 13.2.

\section{RESULTS AND DISCUSSION}

\subsection{Oil content}

The oil contents in the seeds from wild fruits of the caper genotypes are reported in Figure 1. There were significant differences $(P<0.05)$ in oil content among the 


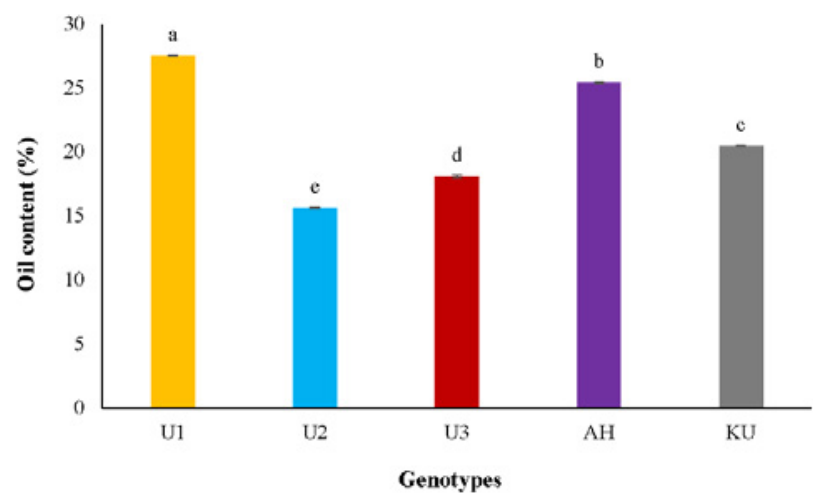

Figure 1. Oil content (g/100 g) of caper seeds in different genotypes. a-e Means (Three experiments) with different letters within treatments were significantly different at the level of $\mathrm{P}<0.05$. Mean comparisons of genotypes were carried out by Duncan's Multiple Range Test (DMRT) at $\alpha=0.05$.

genotypes. Oil contents in samples ranged from 16 to 27\%. Two genotypes (U1 (Urmia) and AH (Ahar)) had significantly higher oil contents than the other genotypes. The highest and the lowest oil contents were found in the U1 (27.50\%) and U2 (16.66\%) (Urmia) genotypes, respectively. El Amri et al. (2019) revealed that the oil content in $C$. spinosa was not only affected by location, but also the highest oil content was observed in big seeds.

These results agree with Tlili et al. (2009), who revealed that oil content in caper seeds ranged from 23 to
$34 \%$ in Tunisia. Zia-Ul-Haq et al. (2011) obtained a similar oil content (29.1\%) in Capparis decidua. Matthäus and Özcan (2005) found that habitat had a high impact on the oil content of Turkish $C$. spinosa seeds. The range of oil content in the present study was higher than that reported in Italian C. spinosa subsp. Rupestris (Argentieri et al., 2012), which can be related to agro-ecological growing conditions (Čolić et al., 2017). These differences could be due to geographic distribution, soil quality, climatic conditions of an area, and size of seeds and/or using different analysis methods. Caper seeds with high oil content are considered to have potential for food and pharmaceutical applications.

\subsection{Fatty acids composition}

The fatty acid composition of the oil samples is reported in Table 2. Eleven fatty acids were detected in the extracted oils from $C$. spinosa seeds and ranged from C14:0 to $\mathrm{C} 20: 0$. The results showed significant differences $(P<$ $0.01)$ in the fatty acid composition of the oil. Among the fatty acids, the predominant constituent was linoleic acid (C18:2n-6) followed by oleic acid (C18:1n-9), palmitic acid (C16:0) and stearic acid (C18:0). The presence of these fatty acids was also reported in other studies (Akgül and Özcan, 1999; Matthäus and Özcan, 2005; Saadaoui et al., 2015; Tlili et al., 2009; Yuldasheva et al., 2008). The monounsaturated fatty acids in the caper oil were

TABLE 2. Fatty acid composition $(\mathrm{g} / 100 \mathrm{~g})$ in seed oil genotypes of capers.

\begin{tabular}{lccccc}
\hline \multirow{2}{*}{ Fatty acid composition } & \multicolumn{5}{c}{ Genotypes } \\
\cline { 2 - 6 } & $\mathbf{U 1}$ & $\mathbf{U 2}$ & $\mathbf{U 3}$ & $\mathbf{A H}$ & KU \\
\hline Myristic acid; C14:0 & $0.34 \pm 0.01^{\mathrm{b}}$ & $0.25 \pm 0.00^{\mathrm{d}}$ & $0.40 \pm 0.01^{\mathrm{a}}$ & $0.27 \pm 0.00^{\mathrm{c}}$ & $0.27 \pm 0.01^{\mathrm{c}}$ \\
Palmitic acid; C16:0 & $1.87 \pm 0.02^{\mathrm{e}}$ & $6.46 \pm 0.05^{\mathrm{c}}$ & $7.05 \pm 0.04^{\mathrm{b}}$ & $6.39 \pm 0.04^{\mathrm{d}}$ & $7.88 \pm 0.02^{\mathrm{a}}$ \\
Palmitoleic acid; C16:1n-7 & $0.59 \pm 0.09^{\mathrm{c}}$ & $1.68 \pm 0.055^{\mathrm{a}}$ & $1.49 \pm 0.07^{\mathrm{ab}}$ & $1.29 \pm 0.03^{\mathrm{b}}$ & $1.35 \pm 0.04^{\mathrm{ab}}$ \\
Stearic acid; C18:0 & $2.75 \pm 0.05^{\mathrm{a}}$ & $2.29 \pm 0.01^{\mathrm{c}}$ & $2.37 \pm 0.0^{\mathrm{b}}$ & $2.23 \pm 0.02^{\mathrm{c}}$ & $2.71 \pm 0.02^{\mathrm{a}}$ \\
Oleic acid; C18:1n-9 & $38.88 \pm 0.03^{\mathrm{a}}$ & $34.78 \pm 0.03^{\mathrm{b}}$ & $34.18 \pm 0.02^{\mathrm{c}}$ & $34.73 \pm 0.03^{\mathrm{b}}$ & $30.52 \pm 0.05^{\mathrm{d}}$ \\
Linoleic acid; C18:2n-6 & $47.30 \pm 0.02^{\mathrm{c}}$ & $45.59 \pm 0.02^{\mathrm{d}}$ & $45.62 \pm 0.02^{\mathrm{d}}$ & $47.71 \pm 0.02^{\mathrm{b}}$ & $49.41 \pm 0.05^{\mathrm{a}}$ \\
$\alpha$-Linolenic acid; C18:3n-3 & $1.33 \pm 0.01^{\mathrm{a}}$ & $1.39 \pm 0.1^{\mathrm{a}}$ & $1.19 \pm 0.02^{\mathrm{ab}}$ & $0.69 \pm 0.01^{\mathrm{c}}$ & $1.07 \pm 0.0^{\mathrm{b}}$ \\
$\gamma$-Linolenic acid; C18:3n-6 & $0.46 \pm 0.00^{\mathrm{c}}$ & $0.49 \pm 0.01^{\mathrm{b}}$ & $0.56 \pm 0.00^{\mathrm{a}}$ & $0.43 \pm 0.00^{\mathrm{d}}$ & $0.47 \pm 0.00^{\mathrm{c}}$ \\
Stearidonic acid; C18:4n-3 & $0.72 \pm 0.03^{\mathrm{bc}}$ & $0.80 \pm 0.03^{\mathrm{a}}$ & $0.78 \pm 0.04^{\mathrm{ab}}$ & $0.71 \pm 0.01^{\mathrm{c}}$ & $0.73 \pm 0.02^{\mathrm{b}^{\mathrm{b}}}$ \\
Arachidic acid; C20:0 & $0.59 \pm 0.02^{\mathrm{b}}$ & $0.74 \pm 0.02^{\mathrm{a}}$ & $0.69 \pm 0.05^{\mathrm{a}}$ & $0.53 \pm 0.04^{\mathrm{b}}$ & $0.51 \pm 0.03^{\mathrm{b}}$ \\
UFA & $89.28 \pm 1.32^{\mathrm{a}}$ & $84.73 \pm 1.75^{\mathrm{bc}}$ & $83.82 \pm 1.01^{\mathrm{c}}$ & $85.56 \pm 0.71^{\mathrm{b}}$ & $83.55 \pm 0.91^{\mathrm{c}}$ \\
SFA & $5.55 \pm 0.45^{\mathrm{d}}$ & $9.74 \pm 0.71^{\mathrm{bc}}$ & $10.51 \pm 0.54^{\mathrm{ab}}$ & $9.42 \pm 0.09^{\mathrm{c}}$ & $11.37 \pm 0.42^{\mathrm{a}}$ \\
\hline
\end{tabular}

UFA: Unsaturated fatty acid; SFA: Saturated fatty acid; Values are expressed as means \pm standard deviation $(\mathrm{n}=3)$. ${ }^{\text {a-e }}$ Means (Three experiments) with different letters within the same row were significantly different at the level of $P<0.05$. Mean comparisons of genotypes were carried out by Duncan's Multiple Range Test (DMRT) at $\alpha=0.05$. 
palmitoleic and oleic acid. Our results were in agreement than those reported by Matthäus and Özcan (2005), who determined that linoleic acid (24.6-50.5\%) was the major fatty acid in C. spinosa genotypes. In contrast, other authors found oleic acid as the major fatty acid in caper seed oil (Akgül and Özcan, 1999; Saadaoui et al., 2015; Tlili et al., 2009). Zia-Ul-Haq et al. (2011) reported that the major fatty acids were linoleic acid (47.3\%) followed by oleic acid (33.2\%) in Capparis decidua, which agree with the values reported in the present study. The KU (Kurdis$\tan )$ genotype showed the highest content in linoleic acid, while U2 and U3 (Urmia) the lowest ones. As mentioned above, the second most abundant fatty acid was oleic acid, ranging from 30.52 (KU) to $38.88 \%$ (U1). Myristic acid (C14:0), $\gamma$-linolenic acid (C18:3n-6), stearidonic acid (C18:4n-3) and arashidic acid (C20:0) were present below $1 \%$ in all genotypes. The presence of these minor fatty acids in C. spinosa seed oil was also reported in different studies (Givianrad et al., 2011; Saadaoui et al., 2015; Tlili et al., 2009). The palmitoleic acid (C16:1n-7) in caper genotypes ranged from $0.59 \%$ in $\mathrm{U} 1$ to $1.68 \%$ in $\mathrm{U} 2$. The linolenic acid content varied from 0.69 to $1.33 \%$ in $\mathrm{AH}$ and U2. Stearidonic acid (C18:4n-3) oscillated from 0.71 (AH) to $0.8 \%$ in the (U2) genotype. The lowest amount of $\gamma$-linolenic acid (C18:3n-6) was present $(>0.56 \%)$ in most of the caper genotypes investigated.

The predominant saturated fatty acids in the caper seed oil were palmitic acid (1.87-7.88\%), followed by stearic acid (2.23-2.71\%), arachidic acid (0.51-0.69\%) and myristic acid (0.25-0.40\%). The highest levels of palmitic and stearic acid were observed in the KU genotype and U3 genotype, which contained the highest contents in myristic acid and arashidic acids. A similar fatty acid profile has also been reported for Tunisian C. spinosa. Tunisian genotypes showed higher myristic, palmitic, palmitoleic, and oleic acid contents and the lowest amount of linoleic acid compared to our genotypes. There was a large variation in palmitic, oleic, linoleic and palmitoleic acids in comparison with stearic and stearidonic acids. The U1 genotype showed the highest content in unsaturated fatty acid. According to some reports, ecological conditions, genetic variation, seed maturity, seed production environment and geographical origin can affect the fatty acid composition of seeds (Acar et al., 2008; Saadaoui et al., 2015; Saxena et al., 2017), which could explain the differences found in the present research.

Several investigations were conducted to demonstrate the effect of different fatty acids on human health. To this regard, it is well known that saturated fatty acids have negative effects on health and promote the appearance of various diseases. A recent study published by The Word Health Organization about the effects of SFA on serum lipids and lipoproteins concluded that each $1 \%$ of dietary energy as SFA replaced with an equivalent amount of cis-
PUFA or cis-MUFA resulted in a significant reduction in total, LDL and HDL cholesterol and in triglyceride contents (Mensink, 2016). In a similar way, a study reviewed the effect of fatty acids on health found that the intake of SFA increased LDL-cholesterol, favored inflammation processes and was associated with an increased incidence of type 2 diabetes (Calder, 2015). However, this evidence has been questioned by recent systematic reviews and meta-analyses of data on mortality in relation to exposure to SFA either through the diet or in the bloodstream.

On the other hand, the replacement of SFA with MUFA, particularly oleic acid, may improve glucose control and insulin sensitivity and would be expected to lower the risk of cardiovascular disease (Calder, 2015). In the same way, the consumption of PUFA, especially n-3 fatty acids, has a high impact on health and plays an important role in the prevention of cardiovascular disease. (Nagy and Tiuca, 2017).

Therefore, with the aforementioned, the caper could be an excellent source for obtaining healthy oil with potential use in the food industry. In fact, caper seeds presented higher amounts of oil content and unsaturated (linoleic and oleic acids) fatty acids. In addition, the U1 and AH genotypes showed the higher oil and unsaturated fatty contents and the lowest amounts of saturated fatty acids. Therefore, these two genotypes could be the best options for food application.

\subsection{Correlation analysis}

The results of the simple correlation coefficients of oil content and fatty acids are presented in Table 3 . Studies have shown fatty acid levels do not affect oil content (Johansson et al., 2000; Onemli, 2012). A significant positive correlation was observed between myristic acid and $\alpha$-linolenic acid $\left(\mathrm{r}=0.646^{* *}\right)$.

Palmitic acid was positively correlated $\left(\mathrm{r}=0.833^{* *}\right)$ with palmitoleic acid and negatively correlated $(\mathrm{r}=$ $-0.920 * *)$ with oleic acid. The negative correlation was revealed when palmitic acid increased and oleic acid decreased. The results agreed with previous reports by multiple authors (Lamaisri et al., 2015; Raheja et al., 1987). Stearidonic acid showed to correlate positively with palmitoleic acid, $\gamma$-linolenic acid and arachidic acid and negatively with linoleic acid.

A positive significant correlation was observed between stearic acid and linoleic acid $\left(\mathrm{r}=0.566^{*}\right)$. However, observed differences between $C$. spinosa seeds from different habitats were similar to the data published by Onemli (Onemli, 2012). Negative correlations existing between linoleic and $\gamma$-linolenic acid can be shown by $\alpha$ and $\gamma$-linolenic acids synthesized by the desaturation of linoleic acid in plants. This is in agreement with results found by other reports by Johansson et al (Johansson et 
TABLE 3. Correlation coefficients among fatty acid composition of the caper genotypes

\begin{tabular}{|c|c|c|c|c|c|c|c|c|c|c|}
\hline Fatty acids & C14:0 & C16:0 & C16:1n-7 & C18:0 & C18:1n-9 & C18:2n-6 & C18:3n-3 & C18:3n-6 & C18:4n-3 & C20:0 \\
\hline $\mathrm{C} 14: 0$ & 1 & & & & & & & & & \\
\hline $\mathrm{C} 16: 0$ & -0.253 & 1 & & & & & & & & \\
\hline C16:1n-7 & -0.236 & $0.833^{* *}$ & 1 & & & & & & & \\
\hline C18:0 & 0.112 & -0.414 & $-0.606^{*}$ & 1 & & & & & & \\
\hline C18:1n-9 & 0.342 & $-0.920^{* *}$ & $-0.655^{* *}$ & 0.053 & 1 & & & & & \\
\hline C18:2n-6 & -0.423 & 0.107 & -0.256 & $0.566^{*}$ & -0.439 & 1 & & & & \\
\hline C18:3n-3 & 0.232 & -0.327 & -0.073 & 0.321 & 0.300 & -0.460 & 1 & & & \\
\hline C18:3n-6 & $0.646^{* *}$ & 0.345 & 0.422 & -0.144 & -0.186 & $-0.598^{*}$ & 0.457 & 1 & & \\
\hline C18:4n-3 & 0.062 & 0.381 & $0.698^{* *}$ & -0.373 & -0.177 & $-0.614^{*}$ & 0.368 & $0.625^{*}$ & 1 & \\
\hline C20:0 & 0.232 & 0.082 & 0.388 & -0.390 & 0.160 & $-0.852^{* *}$ & $0.654^{* *}$ & $0.666^{* *}$ & $0.658^{* *}$ & 1 \\
\hline
\end{tabular}

* Correlation is significant at the 0.05 level, ** Correlation is significant at the 0.01 level. C14:0; Myristic acid, C16:0; Palmitic acid, C16:1n-7; Palmitoleic acid, C18:0; Stearic acid, C18:1n-9; Oleic acid, C18:2n-6; Linoleic acid, C18:3n-3; $\alpha$-Linolenic acid, C18:3n-6; $\gamma$-Linolenic acid, C18:4n-3; Stearidonic acid, C20:0; Arachidic acid

al., 2000). Arachidic acid in caper oil was positively correlated with $\alpha$-linolenic acid and $\gamma$-linolenic acid.

\subsection{Phytochemicals and antioxidant activity in seeds}

The TPC in the caper seed extracts of the 5 studied genotypes are shown in Figure 2. The amount of TPC varied from 16.3 to $24.2 \mathrm{mg} \mathrm{GAE} / \mathrm{g} \mathrm{DW}$ in the different genotypes. In a recent study, some authors found values between 3 and $10 \mathrm{mg}$ of polyphenols/g DW of C. spinosa flowers (Wojdyło et al., 2019). In contrast, other authors reported that the TPC of the aerial part of C. spinosa ranged between 14.8 and $87.5 \mathrm{mg} \mathrm{GAE} / \mathrm{g}$ in roots and 4.49-58.6 mg GAE/g in roots (Baghiani et al., 2012). Baghiani et al. (2012) reported that the extraction solvent exerted a great influence on TPC contents. They found that the chloroform extract showed the highest levels of TPC followed by ethyl acetate extract and crud extract. This fact could explain the differences reported by different researchers (Alirezalu et al., 2020).

The highest TPC was observed in the KU and U1 genotypes and the lowest content was observed in the U2 seeds. Indeed, climatic factors influenced oxidative stress and the generation of reactive oxygen species in perennial plants and led to excessive phenolic compound production in aggressive environments (Lamien-Meda et al., 2010). Phenolic compounds in plant extracts are considered as minor components for eliciting nutraceuticals, antimicrobial activity and antioxidant properties (Alirezalu et al., 2019). In the present research, the TPC variation was lower than those reported in a previous study (Wojdyło et al., 2019). This authors also reported that cultivar had a significant influence on polyphenol content, which agreed with our results (Wojdyło et al., 2019).
As shown in Figure 3, the concentration of flavonoids in seed extracts varied from 1.48 to $3.05 \mathrm{mg} \mathrm{QE} / \mathrm{g}$ DW. All the extracts analyzed showed high TFC. The data showed that the highest TFC was measured in the $\mathrm{KU}$ genotype and the lowest content was observed in U2 genotype. According with Mamati et al. (2006), different biosynthetic pathway of phenolic compounds and related enzyme expression in the growth stages can be effected by the phenolic content in plants. Baghiani et al. (2012) reported values of TFC which range between 23.5 and $298 \mathrm{mg} \mathrm{QE} / \mathrm{g}$ in aerial parts and between 0.25 and 2.12 $\mathrm{mg} \mathrm{QE} / \mathrm{g}$ in roots. These authors found that ethyl acetate was the best solvent to extract flavonoids from plant material. This aspect could explain, in part, the differences found between this research and our data. Health benefits, especially the antioxidant potential of food, depend on the type and amount of flavonoids (Wojdyło et al., 2019). As mentioned for TPC, the cultivar, genotypes and different caper organs (flowers, berries, leaves, seeds) also had a significant influence on the TFC content (Baghiani et al., 2012b; Wojdyło et al., 2019), which agree with the variations observed in the present study.

The antioxidant activity of extracts from the caper seeds of different genotypes is presented in Figure 4. The values for DPPH radical scavenging activity were directly dependent on the level of total phenolic compounds present in the methanolic extracts. The results of DPPH radical scavenging activity of seed extracts ranged between 35 and $63 \%$. The highest free radical scavenging properties were obtained in the seed extract from the KU genotype followed by the extracts from $\mathrm{AH}>\mathrm{U} 1>\mathrm{U} 3>\mathrm{U} 2$. The phenolic compounds and related antioxidant activity of different seeds were analyzed, and it was observed that there was a significant $(P<0.05)$ linear correlation among TPC, TFC and antioxidant capacities (Katalinic et al., 2006). 


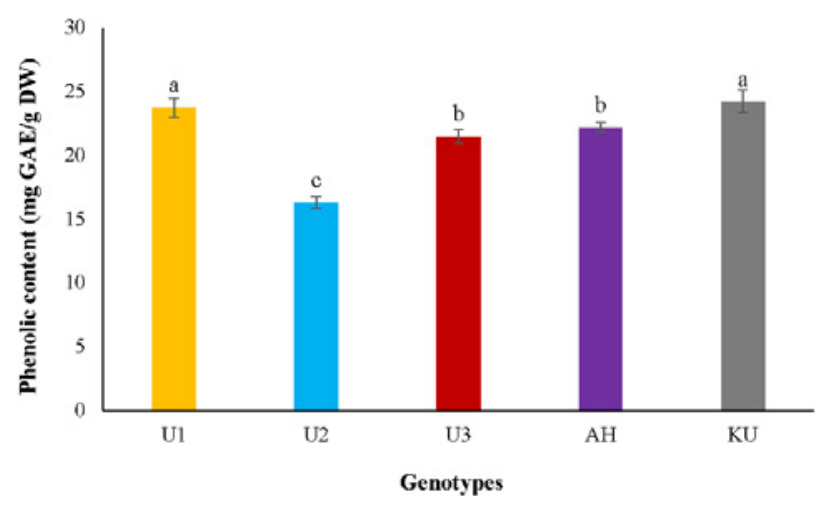

FIGURE 2. Phenolic contents (mg GAE/g DW) of methanolic extracts from caper seeds of different genotypes. ${ }^{\text {a-c }}$ Means (Three experiments) with different letters within treatments were significantly different at the level of $P<0.05$. Mean comparisons of genotypes were carried out by Duncan's Multiple Range Test (DMRT) at $\alpha=0.05$.

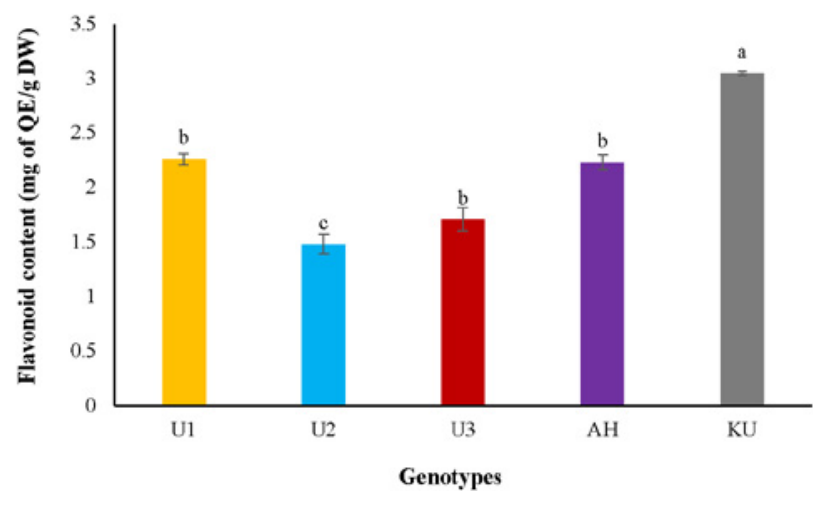

Figure 3. Flavonoid contents (mg QE/g DW) of methanolic extracts from caper seeds in different genotypes. ${ }^{\mathrm{a}-\mathrm{c}}$ Means (Three experiments) with different letters within treatments were significantly different at the level of $P<0.05$. Mean comparisons of genotypes were carried out by Duncan's Multiple Range Test (DMRT) at $\alpha=0.05$.

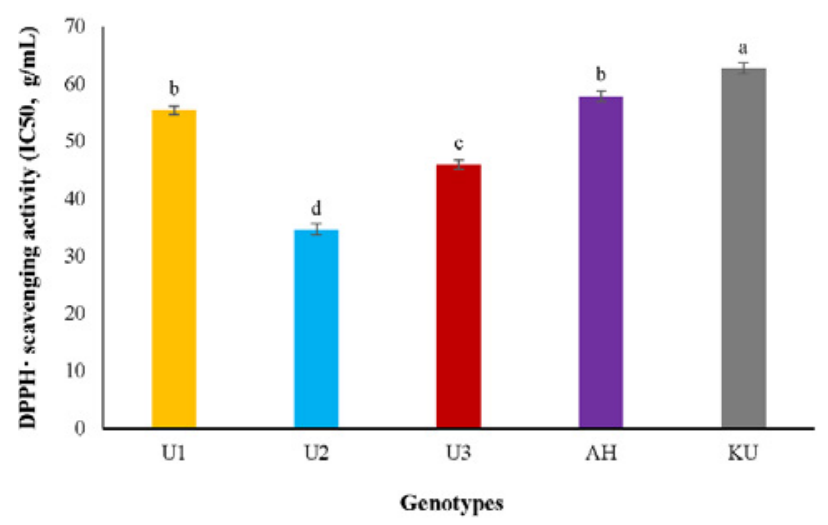

FIgURE 4. Antioxidant activity (\%) of methanolic extracts from caper seeds in different genotypes. ${ }^{\mathrm{a}-\mathrm{d}}$ Means (Three experiments) with different letters within treatments were significantly different at the level of $P<0.05$. Mean comparisons of genotypes were carried out by Duncan's Multiple Range Test (DMRT) at $\alpha=0.05$.
Wojdyło et al. (2019) found 34 flavonols, 10 hydroxycinnamic acids, and 5 flavan-3-ols in C. spinosa flowers. From flavonols, these authors found derivatives of quercetin, kaempferol, isorhamnetin, myricetin and rutin. They also found $(+)$-catechin and (-)-epicatechin and dimers and trimmers from procyanidins (flavan-3-ols) and ferulic, sinapic, quinic, coumaroylquinic and caffeoylquinic acids and their derivatives (hydroxycinnamic acid derivatives). It is well known that these compounds present high antioxidant activity. El-Ghorab et al. (2007) found that the dichloromethane and methanol extracts from caper buds and leaves exhibited higher antioxidant activities than those of their essential oils in testing systems.

The KU genotype contained high amounts of TPC and TFC and showed high antioxidant activity. Several studies have reported that the phenolic compound in plants through their scavenging or chelating activity are associated with their antioxidant activities, their free radical scavenging activity is attributed to free hydroxyl groups (Chang et al., 2001; Ghafar et al., 2017; Ghimire et al., 2011; Ibrahim and El-Masry, 2016). In addition, flavonoids, in fact are a large group of plant phytochemicals as powerful antioxidants with potent free radical scavenging properties and whose utilization as regulators of redox-sensitive signalling pathways is of great interest (Izzi et al., 2012). Thus, the variation in antioxidant activity between genotypes was directly related with the phenolic contents. Some studies on the phytochemical composition of various extracts from C. spinosa have proven the presence of several bioactive compounds such as vitamins, polyphenols and flavonoids, which are known for antioxidant properties which extend the shelf-life of foods (Matsuyama et al., 2009). Tlili et al. (2010) reported that $C$. spinosa extract is rich in phenolic compounds and vitamin antioxidants and can be used as a promising constituent for increasing the nutritional and medicinal properties of foods.

\subsection{Principal component (PCA) and hierarchical cluster analysis (HCA)}

The scores for the principal component analysis of caper genotypes are presented in Figure 5A. The first two principal components accounted for $78 \%(\mathrm{PC} 1=25 \%$ and $\mathrm{PC} 2=$ $53 \%$, respectively) of the total variation. The characteristics that contributed positively to PC1 were oil content, linoleic acid, stearic acid, antioxidant activity, TPC, and TFC; whereas negative contributions were observed for stearidonic acid, arachidic acid, $\gamma$-linolenic acid, palmitoleic acid, $\alpha$-linolenic acid and palmitic acid. PC2 was mainly correlated positively with palmitic acid and palmitoleic acid.

The biplot showed three distinct groups. The first group, comprised of two genotypes (U2 and U3) and was collated from the Urmia province. It was characterized by high amounts of stearidonic acid, $\gamma$-linolenic acid and arachidic acid along with the lowest amount of total phenols. 

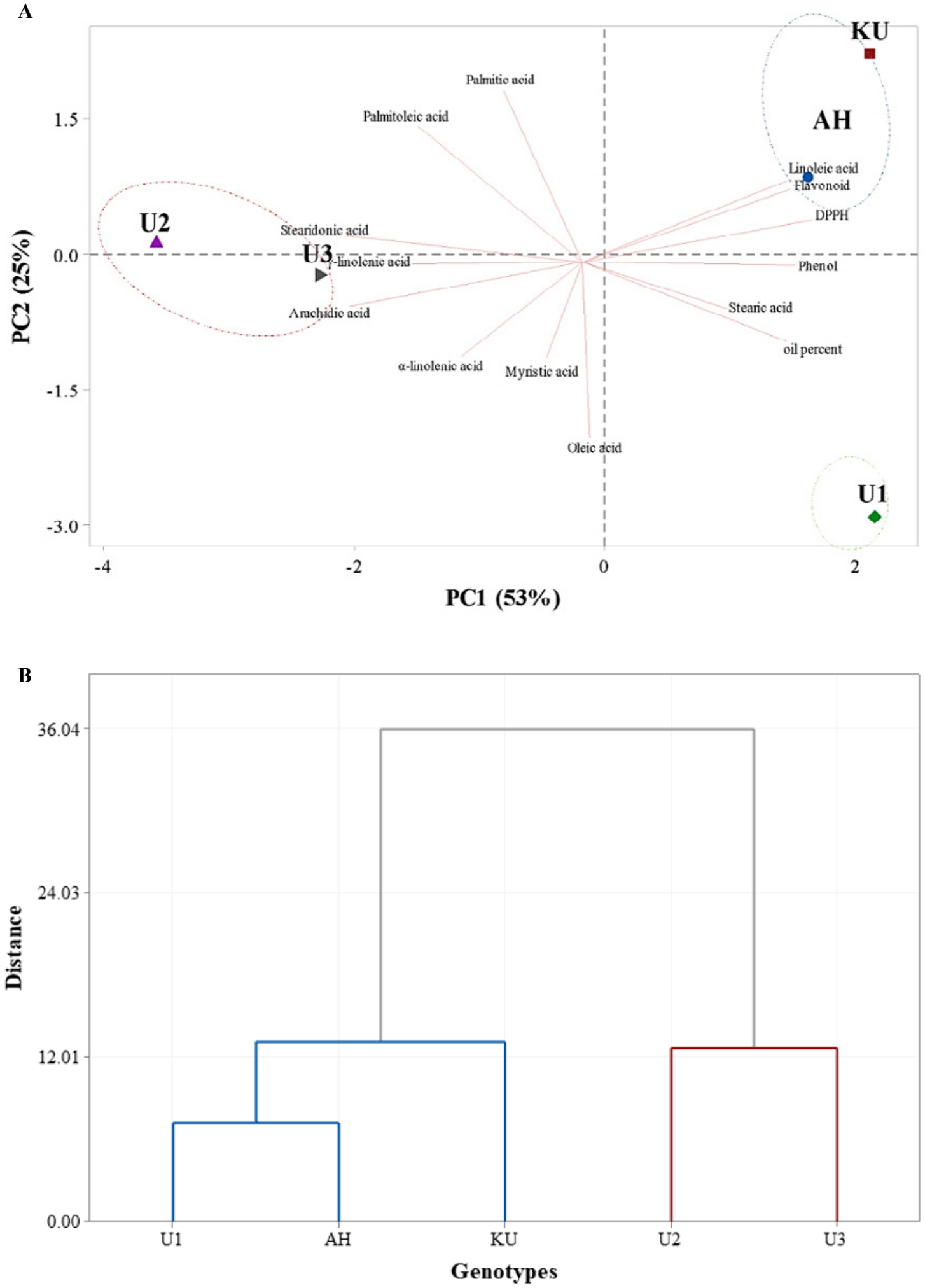

FIGURE 5. A. Principal component analysis (PCA) of caper genotypes; B. Hierarchical cluster analysis (HCA) caper genotypes 
The second group included $\mathrm{AH}$ and $\mathrm{KU}$ genotypes and was characterized by the highest contents in linoleic acid, TFC and antioxidant activity by DPPH assay confirmed that antioxidant activity was mainly due to the presence of flavonoid compounds in caper seeds. The third group (U1 genotype) had the highest amount of oil content, stearic acid and phenols.

A cluster analysis (HCA) of 5 genotypes of capers is shown in Figure 5B. The cluster analysis was performed using antioxidant activity (by DPPH assay), total phenol, total flavonoid, oil content and fatty acid composition. In this case, 5 genotypes were divided into two main clusters. The U2 and U3 genotypes were grouped into the first cluster. They had high amounts of stearidonic acid, $\gamma$-linolenic acid and arachidic acid and the lowest amounts of total phenols, total flavonoids, antioxidant activity and oil content. The second cluster was comprised of three genotypes including $\mathrm{U} 1, \mathrm{AH}$ and $\mathrm{KU}$ with high amounts of linoleic acid, stearic acid, total phenols, total flavonoids, oil content and antioxidant activity.

Generally, variation in fatty acid composition, TPC, TFC and antioxidant activity was detected among the genotypes grown in West Iran. Genetic variability in capers may be utilized in trait-specific breeding programs. These results showed that the seeds of capers are promising sources of natural antioxidants, unsaturated fatty acids and bioactive compounds which are beneficial to the food and pharmaceutical industries. Based on the obtained results, U1 and KU genotypes are the most suitable to be used in breeding programs due to their unsaturated fatty acids, phenolic compounds and antioxidant activity.

\section{CONCLUSIONS}

To the best of our knowledge, this report is the first study on oil content and fatty acid composition combined with phenolic compounds and antioxidant activity in $C$. spinosa seeds collected from different genotypes from Iran. The oils obtained from C. spinosa seeds of different genotype had different chemical compositions and antioxidant activity. The extracted oil from U1 constituted high levels of oil content and unsaturated fatty acids. The extract from KU was rich in TPC, TFC and showed the highest free radical scavenging activity. In conclusion, the $C$. spinosa seeds showed efficient antioxidant potential and can be an alternative for synthetic antioxidants in food and pharmaceutical products. In addition, the high oil content and special unsaturated composition make $C$. spinosa seeds a potential healthy oil source which can be used in the reformulation of several foods.

\section{ACKNOWLEDGMENTS}

This study was supported by Urmia University, Urmia, Iran.

\section{REFERENCES}

Acar M, Mettetal JT, Van Oudenaarden A. 2008. Stochastic switching as a survival strategy in fluctuating environments. Nat. Genet. 40, 471-475. https://doi. org/10.1038/ng.110

Akgül A, Özcan M. 1999. Some compositional characteristics of capers (Capparis spp.) seed and oil. Grasas Aceites 50, 49-52. https://doi.org/10.3989/gya.1999. v50.i1.635

Alirezalu A, Ahmadi N, Salehi P, Sonboli A, Alirezalu K, Khaneghah AM, Lorenzo JM. 2020. Physicochemical characterization, antioxidant activity, and phenolic compounds of hawthorn (Crataegus spp.) fruits species for potential use in food applications. Foods. 9, 436-451. https://doi.org/10.3390/foods9040436

Alirezalu A, Salehi P, Ahmadi N, Sonboli A, Aceto S, Maleki HH, Ayyari M. 2018. Flavonoids profile and antioxidant activity in flowers and leaves of hawthorn species (Crataegus spp.) from different regions of Iran. Int. J. Food Prop. 21, 452-470. https://doi.org/10 $.1080 / 10942912.2018 .1446146$

Alirezalu K, Azadmard-Damirchi S, Fathi Achachlouei B, Hesari J, Emaratpardaz J, Tavakolian R. 2016. Physicochemical properties and nutritional composition of black truffles grown in Iran. Chem Nat. Compd. 52, 290-293. https://doi.org/10.1007/s10600-016-1617-4

Alirezalu K, Hesari J, Nemati Z, Munekata PES, Barba FJ, Lorenzo JM. 2019. Combined effect of natural antioxidants and antimicrobial compounds during refrigerated storage of nitrite-free frankfurter-type sausage. Food Res. Int. 120, 839-850. https://doi.org/https:// doi.org/10.1016/j.foodres.2018.11.048

Alirezalu K, Pateiro M, Yaghoubi M, Alirezalu A, Peighambardoust SH, Lorenzo JM. 2020. Phytochemical constituents, advanced extraction technologies and techno-functional properties of selected Mediterranean plants for use in meat products. A comprehensive review. Trends Food Sci. Technol. 100, 292-306. https://doi.org/10.1016/j.tifs.2020.04.010

Argentieri M, Macchia F, Papadia P, Fanizzi FP, Avato P. 2012. Bioactive compounds from Capparis spinosa subsp. rupestris. Ind. Crops Prod. 36, 65-69. https:// doi.org/10.1016/j.indcrop.2011.08.007

Arslan D, Özcan M. 2007. Effect of some organic acids, yoghurt, starter culture and bud sizes on the chemical properties of pickled caper buds. J. Food Sci. Technol. 44, 66-69.

Ayabe S, Akashi T. 2006. Cytochrome P450s in flavonoid metabolism. Phytochem. Rev. 5, 271-282. https://doi. org/10.1007/s11101-006-9007-3

Azadmard-Damirchi S, Dutta PC. 2006. Novel solid-phase extraction method to separate 4-desmethyl-, 4-monomethyl-, and 4,4'-dimethylsterols in vegeta- 
ble oils. J. Chromatogr. A. 1108, 183-187. https://doi. org/10.1016/j.chroma.2006.01.015

Baghiani A, Ameni D, Boumerfeg S, Adjadj M, Djarmouni M, Charef N, Arrar L. 2012. Studies of antioxidants and xanthine oxidase inhibitory potentials of root and aerial parts of medicinal plant Capparis spinosa L. Am. J. Med. Med. Sci. 2, 25-32. https://doi. org/10.5923/j.ajmms.20120201.06

Bakr RO, El Bishbishy MH. 2016. Profile of bioactive compounds of Capparis spinosa var. Aegyptiaca growing in Egypt. Bras. J. Farmacogn. 26, 514-520. https://doi.org/10.1016/j.bjp.2016.04.001

Boissier E. 1867. Flora Orientalis sive enumeratio plantarum in Oriente a Graecia et Aegypto ad Indiae fines hucusque observatarum. H. Georg, Basel, Geneve. https://doi.org/10.5962/bhl.title.20323

Calder PC. 2015. Functional roles of fatty acids and their effects on human health. J. Parenter. Enteral. Nutr. 39, 18S-32S. https://doi.org/10.1177/0148607115595980

Chang ST, Wu JH, Wang SY, Kang PL, Yang NS, Shyur LF. 2001. Antioxidant activity of extracts from Acacia confusa Bark and Heartwood. J. Agric. Food Chem. 49, 3420-3424. https://doi.org/10.1021/jf0100907

Čolić SD, Fotirić Akšić MM, Lazarević KB, Zec GN, Gašić UM, Dabić Zagorac D, Natić MM. 2017. Fatty acid and phenolic profiles of almond grown in Serbia. Food Chem. 234, 455-463. https://doi.org/10.1016/j. foodchem.2017.05.006

Duman E, Özcan MM. 2014. Mineral contents of seed and seed oils of Capparis species growing wild in Turkey. Environ. Monit. Assess. 186, 239-245. https://doi. org/10.1007/s10661-013-3369-y

Domínguez R, Gullón P, Pateiro M, Munekata PES, Zhang W, Lorenzo JM. 2020. Tomato as potential source of natural additives for meat industry. A review. Antioxidants 9, 73. https://doi.org/10.3390/antiox9010073

El amri N, Errachidi F, Bour A, Bouhaddaoui S, Chabir R. 2019. Morphological and nutritional properties of moroccan Capparis spinosa seeds. Scienti. World J. 8594820. https://doi.org/10.1155/2019/8594820

El-Ghorab A, Shibamoto T, Özcan MM. 2007. Chemical composition and antioxidant activities of buds and leaves of capers (Capparis ovata Desf. var. canescens) cultivated in Turkey. J. Essent. Oil Res. 19, 72-77. https://doi.org/10.1080/10412905.2007.9699233

El-Waseif MA, Badr SA. 2018. Using Egyptian caper seeds oil (Capparis spinosa $\mathrm{L}$ ) as a natural antioxidant to improving oxidative stability of frying oils during deep fat frying. World J. Dairy Food Sci. 13, 18-30. https://doi.org/10.5829/idosi.wjdfs.2018.18.30

Fazio A, Plastina P, Meijerink J, Witkamp RF, Gabriele B. 2013. Comparative analyses of seeds of wild fruits of Rubus and Sambucus species from Southern Italy: Fatty acid composition of the oil, total phenolic con- tent, antioxidant and anti-inflammatory properties of the methanolic extracts. Food Chem. 140, 817-824. https://doi.org/10.1016/j.foodchem.2012.11.010

Ghafar F, Tengku Nazrin TNN, Mohd Salleh MR, Nor Hadi N, Ahmad N, Hamzah AA, Azman IN. 2017. Total phenolic content and total flavonoid content in Moringa oleifera seed. Herit. Sci. 1, 23-25. https://doi. org/10.26480/gws.01.2017.23.25

Ghimire B, Seong E, Kim E, Ghimeray A, Yu C, Ghimire B, Min Chung I. 2011. A comparative evaluation of the antioxidant activity of some medicinal plants popularly used in Nepal. J. Med. Plant Res. 5, 1884-1891. https://doi.org/10.5897/JMPR.9000006

Givianrad MH, Saffarpour S, Beheshti P. 2011. Fatty acid and triacylglycerol compositions of Capparis spinosa seed oil. Chem. Nat. Compd. 47, 798-799. https://doi. org/10.1007/s10600-011-0063-6

Hedge IC, Lamond J. 1970. Capparidaceae. In: Rechinger KH (ed) Flora Iranica, vol 68. Akademische Druck-u, Verlagsanstalt, Graz, pp. 1-9.

Ibrahim M, El-Masry H. 2016. Phenolic content and antioxidant activity of cantaloupe (Cucumis melo var. cantalupensis) and food application. Int. J. Food Sci. Nutr. 5, 24. https://doi.org/10.11648/j.ijnfs.20160501.13

Izzi V, Masuelli L, Tresoldi I, Sacchetti P, Modesti A, Galvano F, Bei R. 2012. The effects of dietary flavonoids on the regulation of redox inflammatory networks. Front. Biosci. 17, 2396-2418. https://doi.org/10.2741/4061

Johansson A, Laine T, Linna MM, Kallio H. 2000. Variability in oil content and fatty acid composition in wild northern currants. Eur. Food Res. Technol. 211, 277-283. https://doi.org/10.1007/s002170000151

Katalinic V, Milos M, Kulisic T, Jukic M. 2006. Screening of 70 medicinal plant extracts for antioxidant capacity and total phenols. Food Chem. 94, 550-557. https:// doi.org/10.1016/j.foodchem.2004.12.004

Lamaisri C, Punsuvon V, Chanprame S, Arunyanark A, Srinives P, Liangsakul P. 2015. Relationship between fatty acid composition and biodiesel quality for nine commercial palm oils. Songklanakarin J. Sci. Technol. 37, 389-395.

Lamien-Meda A, Nell M, Lohwasser U, Börner A, Franz C, Novak J. 2010. Investigation of antioxidant and rosmarinic acid variation in the sage collection of the genebank in gatersleben. J. Agric. Food Chem. 58, 3813-3819. https://doi.org/10.1021/jf903993f

Liu Q, Yao H. 2007. Antioxidant activities of barley seeds extracts. Food Chem. 102, 732-737. https://doi. org/10.1016/j.foodchem.2006.06.051

Lorenzo JM, Munekata PES, Sant'Ana AS, Carvalho RB, Barba FJ, Toldrá F, Trindade MA. 2018. Main characteristics of peanut skin and its role for the preservation of meat products. Trends Food Sci. Tech. 77, 1-10. https://doi.org/10.1016/J.TIFS.2018.04.007 
Mamati GE, Liang Y, Lu J. 2006. Expression of basic genes involved in tea polyphenol synthesis in relation to accumulation of catechins and total tea polyphenols. J. Sci. Food Agri. 86, 459-464. https://doi. org/10.1002/jsfa.2368

Matthäus B, Özcan M. 2005. Glucosinolates and fatty acid, sterol, and tocopherol composition of seed oils from Capparis spinosa var. spinosa and Capparis ovata Desf. var. canescens (Coss.) Heywood. J. Agri. Food Chem. 53, 7136-7141. https://doi.org/10.1021/ jf051019u

Mensink RP. 2016. Effects of saturated fatty acids on serum lipids and lipoproteins: a systematic review and regression analysis. In $\mathrm{WHO}$ (1st ed.). Retrieved from https://www.who.int/nutrition/publications/nutrientrequirements/sfa_systematic_review/e/

Nagy K, Tiuca ID. 2017 . Importance of fatty acids in physiopathology of human body. In A. Catala (Ed.), Fatty Acids (1st ed.,pp. 3-22). https://doi.org/10.5772/67407

Nakajima JI, Tanaka I, Seo S, Yamazaki M, Saito K. 2004. LC/PDA/ESI-MS profiling and radical scavenging activity of anthocyanins in various berries. J. Biomed. Biotechnol. 2004 241-247. https://doi.org/10.1155/ S1110724304404045

Onemli F. (2012). Impact of climate change on oil fatty acid composition of peanut (Arachis hypogaea L.) in three market classes. Chil. J. Agric. Res. 72, 483-488. https://doi.org/10.4067/S0718-58392012000400004

Özcan MM. 2008. Investigation on the mineral contents of Capers (Capparis spp.) seed oils growing wild in Turkey. J. Med. Food. 11, 596-599. https://doi. org/10.1089/jmf.2007.0500

Özcan M, Haciseferogulları H, Demir F. 2004. Some physico-mechanic and chemical properties of capers (Capparis ovata Desf. var. canescens (Coss.) Heywood) flower buds. J. Food Eng. 65,151-155. https:// doi.org/10.1016/j.jfoodeng.2004.01.006

Ordoñez AAL, Gomez JD, Vattuone MA, Isla MI. 2006. Antioxidant activities of Sechium edule (Jacq.) Swartz extracts. Food Chem. 97, 452-458. https://doi. org/10.1016/j.foodchem.2005.05.024

Raheja RK, Batta SK, Ahuja KL, Labana KS, Singh M. 1987. Comparison of oil content and fatty acid composition of peanut genotypes differing in growth habit. Qualitas Plantarum Plant Foods for Hum. Nutr. 37, 103-108. https://doi.org/10.1007/BF01092045

Saadaoui E, Guetat A, Massoudi C, Tlili N, Khaldi A. 2015. Wild Tunisian Capparis spinosa L.: subspecies and seed fatty acids. Int. J. Curr. Res. Acad. Rev. 3 , 315-327.

Savage GP, McNeil DL. Dutta PC. 1997. Lipid composition and oxidative stability of oils in hazelnuts (Corylus avellana L.) grown in New Zealand. J. Am. Oil Chem. Soc. 74, 755-759. https://doi.org/10.1007/ s11746-997-0214-x

Saxena SN, Rathore SS, Diwakar Y, Kakani RK, Kant K, Dubey PN, John S. 2017. Genetic diversity in fatty acid composition and antioxidant capacity of Nigella sativa L. genotypes. LWT - Food Sci. Technol. 78, 198-207. https://doi.org/10.1016/j.lwt.2016.12.033

Shaghaghi A, Alirezalu A, Nazarianpour E, Sonboli A, Nejad-Ebrahimi S. 2019. Opioid alkaloids profiling and antioxidant capacity of Papaver species from Iran. Ind. Crops Prod. 142, 111870. https://doi. org/10.1016/j.indcrop.2019.111870

Singleton VL, Orthofer R, Lamuela-Raventós RM. 1999. Analysis of total phenols and other oxidation substrates and antioxidants by means of folin-ciocalteu reagent. Methods Enzymol. 299, 152-178. https://doi. org/10.1016/S0076-6879(99)99017-1

Tlili N, Munne-Bosch S, Nasri N, Saadaoui E, Khaldi A, Triki S. 2009. Fatty acids, tocopherols and carotenoids from seeds of Tunisian caper "Capparis spinosa". J. Food Lipids. 16, 452-464. https://doi.org/10.1111/ j.1745-4522.2009.01158.x.

Wojdyło A, Nowicka P, Grimalt M, Legua P, Almansa MS, Amorós A, Carbonell-Barrachina AA, Hernández F. 2019. Polyphenol compounds and biological activity of caper (Capparis spinosa L.) flowers buds. Plants. 8, 539-558. https://doi.org/10.3390/plants8120539

Yuldasheva NK, Ul'chenko NT, Glushenkova AI. 2008. Lipids of capparis spinosa seeds. Chem Nat. Compd. 44, 637-638. https://doi.org/10.1007/s10600-0089132-X

Zhang H, Ma ZF. 2018. Phytochemical and pharmacological properties of Capparis spinosa as a medicinal plant. Nutrients 10, 116-130. https://doi.org/10.3390/ nu10020116

Zia-Ul-Haq M, Ćavar S, Qayum M, Imran I, de Feo V. 2011. Compositional studies: Antioxidant and antidiabetic activities of Capparis decidua (Forsk.) Edgew. Int. J. Mol. Sci. 12, 8846-8861. https://doi. org/10.3390/ijms12128846

Zohary M. 1960. The species of Capparis in the Mediterranean and the Near Eastern countries. Bull. Res. Counc. Isr. 8, 49-64. 